\title{
Inhibition of the effect of serotonin on rat ileal transport by cisapride: evidence in favour of the involvement of 5- $\mathrm{HT}_{2}$ receptors
}

\author{
K J MORIARTY, N B HIGGS, M WOODFORD, G WARHURST, \\ AND L A TURNBERG \\ From the Department of Medicine, Hope Hospital (University of Manchester School of Medicine), Salford
}

SUMmaRY Cisapride is a synthetic drug which binds, in vitro, to type 2 serotonin receptors. We examined the influence of serotonin and cisapride on ion transport across intestinal mucosa in vitro and studied the effect of cisapride on the response to serotonin. Segments of ileum of male Sprague-Dawley rats were stripped of muscle layers and mounted in flux chambers. The addition of serotonin $\left(10^{-8}\right.$ to $\left.10^{-4} \mathrm{M}\right)$ to the serosal aspect of the mucosa caused a rapid, dose-dependent rise in short circuit current and transmural potential difference. Cisapride alone $\left(5 \times 10^{-5} \mathrm{M}\right)$, when added to the mucosal and serosal surfaces, had no effect on the short circuit current, transmural potential difference, resistance, or sodium and chloride fluxes across the mucosa. It did, however, inhibit the response of the mucosa to serotonin $\left(10^{-5} \mathrm{M}\right)$ in a dose dependent manner and blocked it completely at a concentration of $5 \times 10^{-5} \mathrm{M}$. Serotonin $\left(5 \times 10^{-5} \mathrm{M}\right)$ increased serosal to mucosal flux of chloride from $12.6 \pm 0.8$ to $15.2 \pm 0.6 \mu \mathrm{mol} / \mathrm{cm}^{2} / \mathrm{h} \quad(\mathrm{p}<0.025)$, thus reducing net chloride absorption from $4.65 \pm 0.81$ to $1.49 \pm 1.04 \mu \mathrm{mol} / \mathrm{cm}^{2} / \mathrm{h}(\mathrm{p}<0.05)$. This effect was completely blocked by cisapride $\left(5 \times 10^{-5} \mathrm{M}\right)$. In summary, cisapride inhibits the effect of serotonin on rat ileal ion transport, probably by blocking type 2 serotonin receptors.

Serotonin $(5-\mathrm{HT})$ is found in high concentrations throughout the gastrointestinal tract of a variety of mammalian species including man. ${ }^{1}$ In the gut, the amine is contained predominantly within the mucosal enterochromaffin cells, ${ }^{2}$ but it is also found in the myenteric plexus, ${ }^{3-5}$ suggesting a neurotransmitter role for 5-HT in the gut. ${ }^{6}$

Serotonin stimulates fluid secretion across a variety of mammalian gastrointestinal epithelia, including rat jejunum ${ }^{7}$ and colon $^{89}$ and rabbit gall bladder, colon, and ileum. ${ }^{10-15}$ It is uncertain, however, whether these effects are mediated via $5-\mathrm{HT}_{1}$ or $5-\mathrm{HT}_{2}$ types of receptor, largely because of a lack of good specific 5-HT blocking agents.

Cisapride (Janssen Pharmaceutica, Beerse, Belgium) is a recently developed drug which stimulates gastrointestinal motor activity in a number of

Address for correspondence: Professor L A Turnberg, Department of Medicine (University of Manchester School of Medicine), Eccles Old Road, Salford M6 8HD.

Received for publication 21 November, 1986. mammalian species including man. ${ }^{16}$ It binds specifically to type 2 serotonin receptors in vitro having no affinity for type 1 serotonin binding sites, ${ }^{17}$ and it antagonises contractions induced by serotonin in the guinea pig ileum and the tail artery of the rat. ${ }^{18}$ The aim of the present study was to examine whether this relatively specific $5-\mathrm{HT}_{2}$ receptor antagonist would help define the type of receptor likely to be involved in mediating the intestinal mucosal response to 5-HT.

\section{Methods}

ANIMALS

Non-fasting male Sprague-Dawley rats were killed by a blow to the head and cervical dislocation. The ileum was removed and stripped of muscle layers. Segments of mucosa were mounted between perspex flux chambers with a surface area of $0.64 \mathrm{~cm}^{2}$. Usually eight tissues from the same animal were mounted so that luminal and basal aspects were each bathed in buffer solution containing $\mathrm{Na}, 146 ; \mathrm{K}, 4 \cdot 2 ; \mathrm{Cl}, 125 \cdot 8$; 
$\mathrm{HCO}_{3}, 26 \cdot 6 ; \mathrm{H}_{2} \mathrm{PO}_{4}, 0 \cdot 2 ; \mathrm{HPO}_{4}, 1 \cdot 2 ; \mathrm{Ca}, 1 \cdot 2 ; \mathrm{Mg}$, 1.2 ; glucose, 10 (all $\mathrm{mmol} / \mathrm{l}) ; \mathrm{pH} 7.4$ at $37^{\circ} \mathrm{C}$. All solutions were continuously oxygenated with $95 \% \mathrm{O}_{2}$ $-5 \% \mathrm{CO}_{2}$.

\section{ELECTRICAL MEASUREMENTS}

The spontaneous transmucosal electrical potential difference (PD) was measured via $3 \mathrm{M} \mathrm{KCl}$ in $3 \%$ agar electrode bridges and matched calomel half cells to a high impedance digital voltmeter. Short circuit current (SCC) was delivered via silver/silver chloride electrodes and $1 \mathrm{M} \mathrm{NaCl}$ in $1 \%$ agar bridges. The electrodes were connected to a voltage clamp for automatic short-circuiting, the clamp being corrected for the fluid resistance between the PD sensing bridges. Tissue resistance (R) was calculated from PD and SCC according to Ohm's law and the SCC in $\mu$ amps was converted to net ionic fluxes as previously described. ${ }^{19}$

RADIO-ISOTOPE FLUXES

Isotopic fluxes were measured after adding $0.5 \mu \mathrm{Ci}$ ${ }^{22} \mathrm{Na}$ and $2.5 \mu \mathrm{Ci}{ }^{36} \mathrm{Cl}$ (Radiochemical Centre, Amersham, Bucks, England) to the mucosal side of

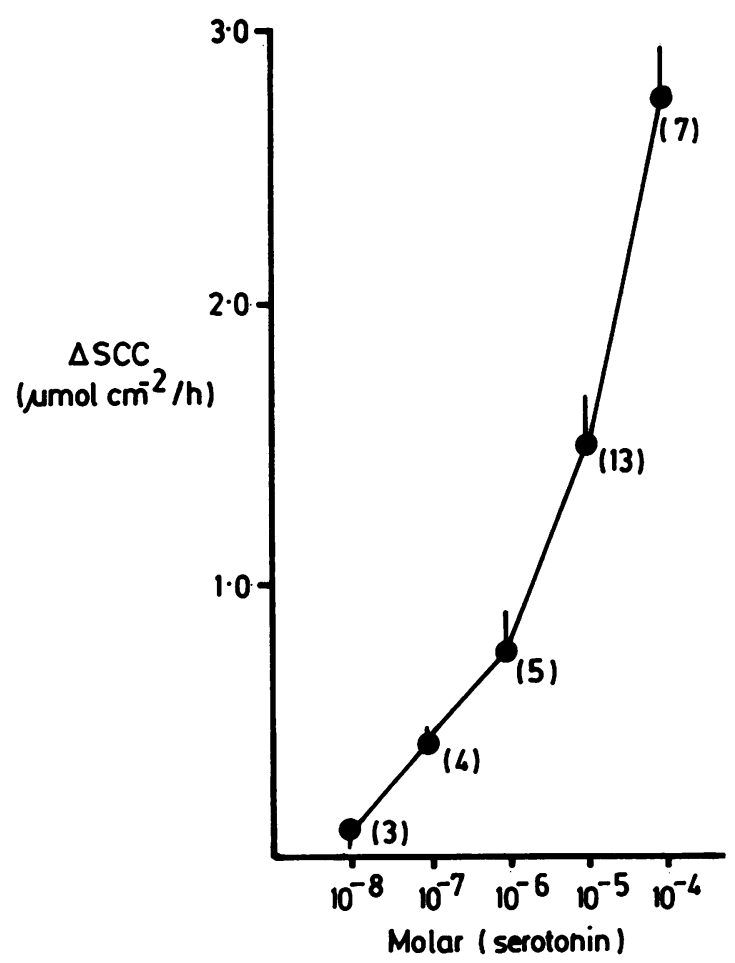

Fig. 1 Influence of serotonin on the peak increments in short circuit current $(\triangle S C C)$. Results are the mean $\pm S E M$. Numbers in brackets represent the numbers of tissues studied at each concentration. one tissue and the serosal side of its paired tissue. Tissues were paired providing their resistances did not differ by more than $25 \%$. The method for determining and calculating the unidirectional fluxes has been described. ${ }^{19}$ The net flux was calculated as the difference between the two unidirectional fluxes. In the flux experiments, isotopes were added immediately after the tissue was mounted. After a 20 minute equilibration period, five consecutive 15 minute fluxes were determined.

\section{CHEMICALS}

Cisapride was supplied by Janssen Pharmaceuticals. It was dissolved in a base containing mannitol and acetic acid. In all experiments, cisapride or the base were added simultaneously to both the mucosal and serosal chambers, 15 minutes before the addition of serotonin. Serotonin (Sigma Chemical Co, St Louis, Missouri, USA) was added to the serosal chamber only.

\section{CALCULATIONS}

Residual ion flux, which is that part of the SCC in $\mu \mathrm{mol} / \mathrm{cm}^{2} / \mathrm{h}$ not accounted for by net movement of $\mathrm{Na}$ and $\mathrm{Cl}$, was calculated as $\mathrm{SCC}-(\mathrm{JNa}$ net $-\mathrm{JCl}$ net).

Statistical comparisons were carried out by the Student's $t$ test. ${ }^{20}$

\section{Results}

ELECTRICAL EXPERIMENTS

Serotonin, when added to the serosal aspect of the mucosa, in concentrations ranging from $10^{-8}$ to $10^{-4} \mathrm{M}$, caused a rapid, dose dependent rise in short circuit current (Fig. 1) and transmucosal electrical potential difference. This response was maximal 60 seconds after the addition of 5-HT and lasted from 15-30 minutes. Transmural resistance was unaltered.

The addition of either cisapride, in concentrations up to $5 \times 10^{-5} \mathrm{M}$, or its base, to the mucosal and serosal aspects of the mucosa had no effect on the short circuit current, transmural potential difference or resistance.

The application of serotonin $\left(10^{-5} \mathrm{M}\right)$ to the serosal aspect of the mucosa caused a rapid increase in shortcircuit current and potential difference. Cisapride, however, inhibited this response in a dose dependent manner and blocked it completely at a concentration of $5 \times 10^{-5} \mathrm{M}$ (Fig. 2).

\section{FLUX EXPERIMENTS}

The influence of serotonin $\left(5 \times 10^{-5} \mathrm{M}\right)$ on net and unidirectional chloride fluxes in the presence and absence of cisapride is shown in Figure 3. Cisapride itself had no effect on net or unidirectional fluxes of 


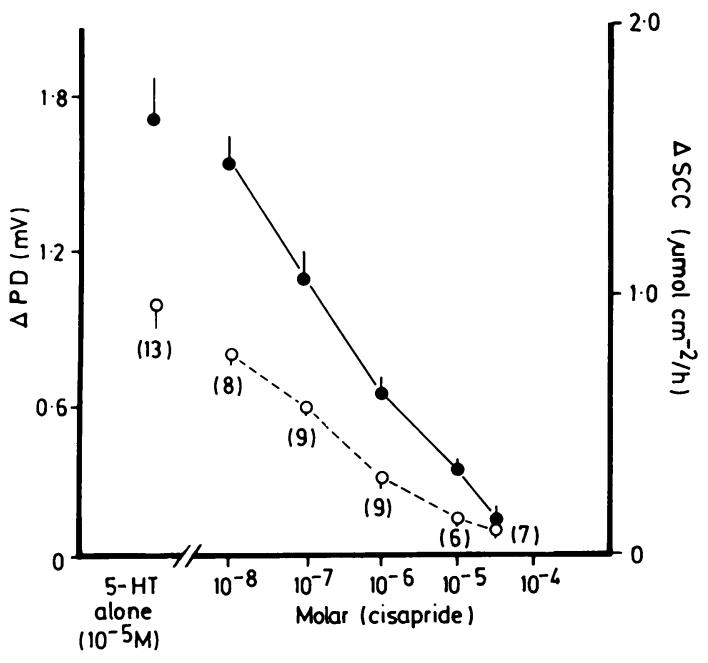

Fig. 2 Influence of increasing concentrations of cisapride on the peak increments in short circuit current (solid line) and transmural electrical potential difference (dashed line), which occurred in response to $10^{-5} \mathrm{M}$ serotonin (5-HT). Cisapride was added 15 mins before serotonin. Numbers in brackets represent the number of tissues studied at each concentration. Results are expressed as the mean $\pm S E M$.

sodium or chloride or on residual ion flux. In contrast, serotonin increased serosal to mucosal flux of chloride from $12 \cdot 6 \pm 0 \cdot 8$ to $15 \cdot 2 \pm 0 \cdot 6 \mu \mathrm{mol} / \mathrm{cm}^{2} / \mathrm{h}$ $(\mathrm{p}<0 \cdot(025)$, thus reducing net chloride absorption from $4.65 \pm 0.81$ to $1.49 \pm 1.04 \mu \mathrm{mol} / \mathrm{cm}^{2} / \mathrm{h}(\mathrm{p}<0.05)$. This effect was completely blocked by cisapride. This change in chloride flux lasted for 15 minutes only (Fig. 3) and corresponded to the time course of the rise in short circuit current and transmucosal electrical potential difference which were observed in response to the secretagogue. Serotonin had no effect on net or unidirectional fluxes of sodium, nor did it have any effect on residual ion flux.

\section{Discussion}

Several studies have shown that serotonin can cause secretion in rat jejunal ${ }^{7}$ and colonic $^{x y}$ mucosa and rabbit ileal and colonic ${ }^{12-15}$ mucosa. The present studies in rat ileum confirm that 5-HT increases serosal to mucosal fluxes of chloride, thereby inhibiting net absorption. In other studies, mucosal to serosal fluxes of sodium and chloride were also inhibited by 5-HT and chloride secretion was thus induced. Differences in species, in region of intestine studied or in dosage of 5-HT used might account for this discrepancy.

The mechanism of action of 5-HT involves a rise in intracellular calcium, ${ }^{12-15}$ but the site and type of serotonin receptor which mediates the response is uncertain. Attempts to show specific binding receptors on epithelial cells from rat intestine ${ }^{21}$ were unsuccessful. On the other hand, if a neural intermediary was involved in the serotonin effects, it would be expected that the nerve blocking agent, tetrodotoxin, would have inhibited responses to 5-HT, but this could not be demonstrated, at least in rat colon."

Whatever the site of 5-HT receptors, the type involved in influencing transport has not been clearly defined, largely because of a lack of specific 5-HT blockers. Serotonin receptors in the brain are classified as either type 1 , which have a high affinity for 5-HT and a low affinity for spiroperidol, or type 2, which have a lower affinity for 5-HT and a higher affinity for spiroperidol..$^{22}{ }^{23}$ In the rat colon, however, neither cinanserin, a potent type 2 antagonist, ${ }^{24}$ nor methysergide, which has a relatively high affinity for type 1 and type 2 receptors, had any effect on the rise in short circuit current induced by 5 -HT. ${ }^{9}$ In contrast, in the rat jejunum, mianserin, a potent type 2 antagonist, but which also possesses weak affinity for type 1 serotonin binding sites, competitively inhibited the response to 5-HT. ${ }^{7}$ The binding affinity of cisapride is moderate for type 2 serotonin receptors, weak for $\alpha_{1}$-adrenergic, absent for serotonin type 1 , and virtually absent for dopamine-2, histamine-1, and muscarinic receptors. ${ }^{17}$ In the present study, cisapride blocked the inhibition of chloride absorption caused by 5-HT. In addition, as in guinea pig ileum and rat colon, ${ }^{25}$ cisapride inhibited the rise in short circuit current and transmucosal electrical potential difference which occurred in response to 5-HT. These findings suggest that 5-HT acts via type 2 serotonin receptors in stripped rat ileum.

In the present study, cisapride itself had no influence on electrical activity or ion fluxes. This and previous similar reports ${ }^{2627}$ suggest that endogenous serotonin does not contribute to the intrinsic transport 'tone' of the stripped rat ileal preparation.

The precise physiological role of 5-HT is unknown, but it is thought that its release postprandially leads to simultaneous increases in intestinal motility, secretion and blood flow, thus facilitating the digestive and absorptive functions of the gut.

Pathophysiologically, raised plasma concentrations of 5-HT are usually the cause of the secretory diarrhoea characteristic of the carcinoid syndrome. ${ }^{2 \times}{ }^{24}$ The findings of the present study would suggest that cisapride may be useful in patients with this syndrome, although its effect on intestinal motility in this condition is unpredictable.

We are grateful to Salford Area Health Authority for 


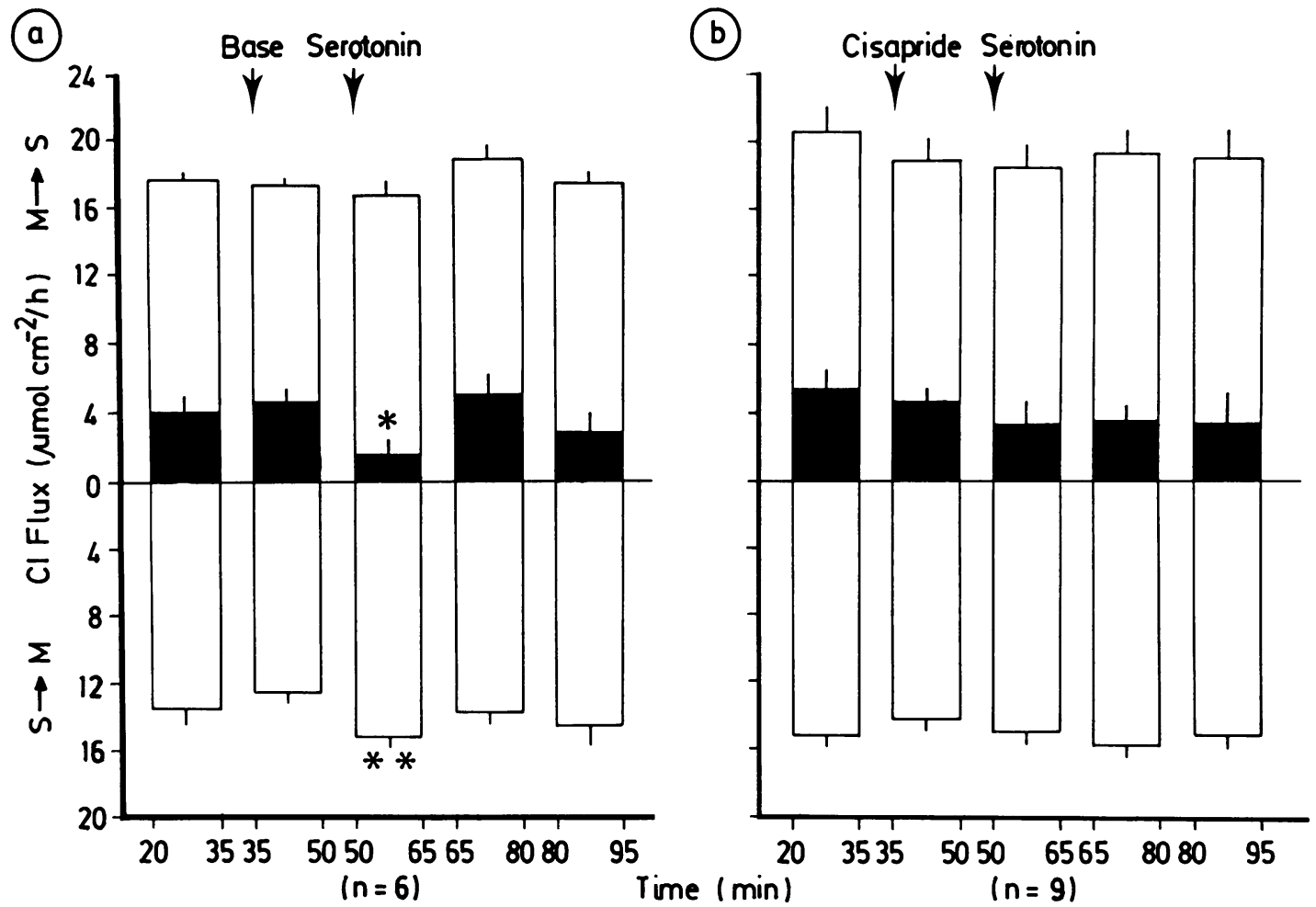

Fig. 3 Influence of serotonin $\left(5 \times 10^{-5} \mathrm{M}\right)$ on net (shaded bars) and unidirectional chloride fluxes in the presence of the base (a) and $5 \times 10^{-5} M$ cisapride (b), $m \rightarrow s$ is mucosal to serosal flux, $s \rightarrow m$ is serosal to mucosal flux. Results are the mean $\pm S E M$. ${ }^{*} p<0 \cdot 05,{ }^{* *} p<0 \cdot 025$. Values refer to the level of significance of the differences between the second and third flux periods.

financial support and to Julie Rostron for typing the manuscript.

\section{References}

1 Thompson JH. Serotonin and the alimentary tract. Res Comm Chem Pathol Pharmacol 1971; 2: 687-781.

2 Erspamer V. Pharmacology of indolealkylamines. Pharmacol Rev 1954; 6: 425-87.

3 Gershon MD, Drakontides AB, Ross LL. Serotonin: synthesis and release from the myenteric plexus of the mouse intestine. Science 1965; 149: 197-9.

4 Rothman TP, Ross LL, Gershon MD. Separately developing axonal uptake of 5-hydroxytryptamine and norepinephrine in the fetal ileum of the rabbit. Brain Res 1976; 115: 437-56.

5 Gintzler AR, Rothman TP, Gershon MD. Ontogeny of opiate mechanisms in relation to the sequential development of neurons known to be components of the guinea pig's enteric nervous system. Brain Res 1980; 189: 31-48.

6 Gershon MD. Putative neurotransmitters: serotonin. In: Burnstock G, Gershon MD, Hökfelt T, Iversen LL, Kosterlitz HW, Szurszewski TH, eds. Neurosciences research program bulletin. Vol. 17. Non-adrenergic, non-cholinergic autonomic neurotrans-mission mechanisms. Cambridge: MIT Press, 1979: 414-24.
7 Hardcastle J, Hardcastle PT, Redfern JS. Action of 5-hydroxytryptamine on intestinal ion transport in the rat. J Physiol 1981; 320: 41-55.

8 Dharmsathaphorn K, Racusen L, Dobbins JW. Effect of somatostatin on ion transport in the rat colon. J Clin Invest 1980; 66: 813-20.

9 Zimmerman TW, Binder HJ. Serotonin-induced alteration of colonic electrolyte transport in the rat. Gastroenterology 1984; 86: 310-17.

10 Kisloff B, Moore EW. Effect of serotonin on water and electrolyte transport in the in vivo rabbit small intestine. Gastroenterology 1976; 71: 1033-8.

11 Donowitz M, Charney AN, Heffernan JN. Effect of serotonin treatment on intestinal transport in the rabbit. Am J Physiol 1977; 232: E85-94.

12 Bolton JE, Field M. Ca ionophore-stimulated ion secretion in rabbit ileal mucosa: relation to actions of cyclic 3',5'-AMP and carbamylcholine. J Membr Biol 1977; 35: 159-73.

13 Sheerin HE. Serotonin action on short-circuit current and ion transport across isolated rabbit ileal mucosa. Life Sci 1979; 24: 1609-16.

14 Donowitz M, Tai YH, Asarkof N. Effect of serotonin on active electrolyte transport in rabbit ileum, gallbladder and colon. Am J Physiol 1980; 239: (Gastrointest Liver Physiol 2): G463-G72.

15 Donowitz M, Asarkof N, Pike G. Calcium dependence 
of serotonin-induced changes in rabbit ileal electrolyte transport. J Clin Invest 1980; 66: 341-52.

16 Van Nueten JM, Van Daele PGH, Reyntjens AJ, Janssen PAJ, Schuurkes JAJ. Gastrointestinal motility stimulating properties of cisapride, a non-antidopaminergic non-cholinergic compound. In: Roman C, ed. Gastrointestinal motility. Lancaster: MTP Press Ltd, 513-20.

17 Leysen JE. In: Cisapride (R51619) - Investigational new drug brochure. Beerse, Belgium: Janssen Pharmaceutica, B-2340, 1985.

18 Schuurkes JAJ, Van Nueten JM, Van Daele PGH, Reyntjens AJ, Janssen PAJ. Motor-stimulating properties of cisapride on isolated gastrointestinal preparations of the guinea pig. J Pharmacol Exp Ther 1985; 234: 775-83.

19 Corbett CL, Isaacs PET, Riley AK, Turnberg LA. Human intestinal ion transport in vitro. Gut 1977; 18: 136-40.

20 Snedecor GW, Cochran WG. Statistical methods. 7th ed. Ames, Iowa: Iowa State University Press, 1980.

21 Gaginella TS, Rimele TJ, Wietecha M. Studies on rat intestinal epithelial cell receptors for serotonin and opiates. J Physiol 1983; 335: 101-11.

22 Peroutka SJ, Snyder SH. Multiple serotonin receptors: differential binding of $\left[{ }^{3} \mathrm{H}\right]$ 5-hydroxytryptamine, $\left[{ }^{3} \mathrm{H}\right]$ lysergic acid diethylamine and $\left[{ }^{3} \mathrm{H}\right]$ spiroperidol. $\mathrm{Mol}$ Pharmacol 1979; 16: 687-99.

23 Peroutka SJ, Lebovitz RM, Solomon HS. Two distinct central serotonin receptors with different physiological functions. Science 1981; 212: 827-9.

24 Leysen JE, Awouters F, Kennis L, Laduron PM, Vandenberk J, Janssen PAJ. Receptor binding profile of $\mathrm{R} 41468$, a novel antagonist at 5- $\mathrm{HT}_{2}$ receptors. Life Sci 1981; 28: 1015-22.

25 Allbee WE, Gaginella TS. Bradykinin-induced electrolyte secretion: Role of serotonin and histamine. Gastroenterology 1985; 88: 1303.

26 Cooke HJ, Carey HV. The effects of cisapride on serotonin-evoked mucosal responses in guinea-pig ileum. Eur J Pharmacol 1984; 98: 147-8.

27 Hardcastle J, Hardcastle PT, Kelleher DK. The action of R51619 on transport processes in the rat small intestine. J Pharm Pharmacol 1984; 36: 139-40.

28 Oates JA, Sjoerdsma A. A unique syndrome associated with secretion of 5-hydroxytryptophan by metastatic gastric carcinoids. Am J Med 1962; 32: 333-42.

29 Donowitz M, Binder HJ. Jejunal fluid and electrolyte secretion in carcinoid syndrome. Am J Dig Dis 1975; 20: 1115-22. 